\title{
Clinton team trims laboratory reform plans
}

Raleigh, North Carolina. Plans by the Clinton administration to streamline the federal laboratory system - including those run by the Department of Energy, the Department of Defense (DoD) and the National Aeronautics and Space Administration (NASA) - are in trouble after separate reviews of each of the three agencies failed to produce coherent proposals for change.

Katherine Gillman, staff director of the interagency review that is being carried out by the White House Office of Science and Technology Policy (OSTP), says that finding overlaps between the reviews is turning out to be difficult. "Maybe what we recommend to the President will be more specific [to each agency] than we had anticipated," she said last week.

\section{Roche asked for more Taq patent evidence}

London. The Swiss pharmaceutical company Hoffman-la Roche has been told by the European Patent Office (EPO) that it needs to carry out further experiments to confirm the difference between its Taq polymerase and similar thermostable enzymes isolated by previous researchers from the same organism before the EPO is prepared to grant the company a patent.

In doing so, the patent office has gone back on a previous decision - communicated to the company last August - indicating that it had agreed to issue the patent on the enzyme (see Nature 372, 212; 1994). Rights to both the enzyme and the polymerase chain reaction (PCR) in which it is used were bought by Roche from the US biotechnology company Cetus in 1991 for the sum of $\$ 300$ million.

Shortly before the patent was due to be granted in December, the EPO received objections from three different sources. The identity of the objectors has not been revealed. But each is believed to have made arguments similar to those put forward by the company Promega in its US challenge to the patent, suggesting that the enzyme 'discovered' by Cetus scientists was identical to that described several times previously in the literature (see Nature 373, 310; 1995).

As a result, the EPO has now decided to take the unusual step of reopening the examination procedure. In particular it has asked Roche to provide further experimental data "to proof [sic] the 'high fidelity' of the claim polymerases in comparison to the polymerases of the state of the art".

This is a reference to a crucial claim in the Roche application, namely that the novelty of its $T a q$ is proved by its significantly greater accuracy in reproducing nucleotide sequences compared to the polymerases that had already been isolated by others.
OSTP is due to report on the future of the government's \$15 billion-a-year laboratory system in April. Its report is supposed to be based on reviews requested from the three agencies. An external review of the Department of Energy laboratories was completed last month by a panel chaired by Bob Galvin of Motorola (see Nature 373, $463 ; 1995)$, and internal reviews were delivered last week by DoD and NASA.

The DoD review suggests that the armed services should continue to run their own laboratories, but contains few concrete proposals for reform. NASA's document calls for each of its laboratories to focus their activities more tightly (see page 107).

Gillman told the annual meeting of the scientific society Sigma Xi at Raleigh, North Carolina, that neither report addressed the central question of how the size of the laboratories can be reduced - as budget projections require - without a civil service-style attrition process that would freeze hiring and cause the best people to leave.

She added that the DoD has tested a new system of hiring and firing civil servants at the China Park base in California which might form the basis for laboratory reform. Meanwhile Galvin has put forward radical proposals to 'corporatize' energy department laboratories; but these may prove to be politically unacceptable.

"The governance problem at the Department of Energy is something that we're going to have to fix," says Gillman. "The laboratories cannot live with the existing system - it is wrecking them." But she added that OSTP could not promise to include firm proposals for the management of the energy laboratories in its long awaited April report.

In fact, the interagency review, which was initiated by Clinton's OSTP as one of its top priorities, has been overshadowed by last November's election result. The White House may now let the Republican majority in Congress take the lead in reforming the federal laboratories, as such reform is bound to be unpopular - at least in the short term.

Colin Macilwain

\section{Breakaway iceberg 'due to warming'}

\author{
IMAGE \\ UNAVAILABLE \\ FOR COPYRIGHT \\ REASONS
}

London. The breaking away of large expanses of ice from the eastern side of the Larsen ice shelf supports the idea that recent ice loss from this region of the Antarctic ice sheets is linked to regional atmospheric warming rather than ocean currents, according to scientists from the British Antarctic Survey (BAS). "It is real confirmation that it is atmospheric changes [that are responsible]," says David Vaughan, a glaciologist with the BAS at Cambridge.

The first image taken by one of five NOAA polar orbiting weather satellites (above left) shows the Antarctic Peninsula $\left(60^{\circ} \mathrm{S}, 60^{\circ} \mathrm{W}\right)$ on 9 January this year. The far right-hand corner of the image is dominated by loose sea ice up to a black line running along the $60^{\circ} \mathrm{W}$ longitude, which is an area of open water just in front of the ice shelf. The ice sheet is marked by striations caused by melt water and a mountain ridge.

Five and a half weeks later (16 February) a $2,400 \mathrm{~km}^{2}$ iceberg, roughly the size of Oxfordshire, had broken away from the ice shelf. This can still be seen on the image (above right) taken on 27 February, which also shows that another section of the ice shelf has broken up into ice rubble.

"We think these represent the second and third break-up of the ice shelf in this area." says Vaughan. The first caused considerable debate on whether the break-up of the ice sheet could be used as a measure of climate change (see Nature 350, 328; 1991). Fiona Gammie 